\title{
RESULTS OF HARVESTERS AND FORWARDERS OPERATIONS IN SLOVAKIAN FORESTS
}

\author{
Marián Slamka, Marián Radocha \\ Forest National Centre - Forest Research Institute Zvolen, T. G. Masaryka 22, \\ SK-96092 Zvolen, e-mail: slamka@nlcsk.org; radocha@nlcsk.org
}

Slamka M., Radocha M.: Results of harvesters and forwarders operations in Slovakian forests. Lesn. Čas. - Forestry Journal, 56(1): 1 - 15, 2010, 6 fig., tab. 6, ref. 14. Original paper. ISSN $0323-10468$

Paper deals with performance, consumption of fuel and negative effects of harvester technologies on remaining stand at some workplaces in Central Slovakia.

Measurements were performed at OZ (affiliated state forest enterprise) Beňuš, Kriváň, Čierny Balog and ProPopulo Poprad Ltd. Harvester and forwarder Valmet 911.1/6 + Valmet 840.1/8, John Deere (JD) 1070 D + JD 810 D, JD 770 D + JD 810 D and JD $1270 \mathrm{D}+1110 \mathrm{D}$ were used. The results show that during wheeled harvesters operation on the slopes with inclination to $40 \%$ it is possible to reach that number of mechanically damaged trees could be on average below $10 \%$. Using statistical verification it was found that treatment intensity influences significantly damage to remaining stand.

Harvester JD 1070 D operating in tending felling reached an average performance only $2.3 \mathrm{~m}^{3} \cdot \mathrm{h}^{-1}$ with average volume of tree $0.14 \mathrm{~m}^{3}$ and slope inclination within $10 \%$. We found that it is possible to reduce to a half the costs of the production of $1 \mathrm{~m}^{3}$ of wood by proper technological preparation of the workplace and modifying the technical parameters of machine according to the parameters of stand where harvesters would operate.

Key words: harvester, forwarder, performance, fuel consumption, damage, remaining stand

Príspevok sa zaoberá zistovaním výkonnosti, spotreby PHM a negatívnych dopadov pôsobenia harvesterových technológií na zostávajúci porast na vybraných pracoviskách v rámci stredného Slovenska.

Merania sa vykonali v rámci OZ Beňuš, Kriváň, Čierny Balog a ProPopulo Poprad, s. r. o., pri práci harvesterových uzlov Valmet 911.1/6 + Valmet 840.1/8, John Deere (JD) 1070 D + JD 810 D, JD 770 D + JD 810 D a JD 1270 D + 1110 D. Dosiahnuté výsledky ukazujú, že pri použití strojov na kolesových podvozkoch na svahoch do sklonu $40 \%$ možno v priemere udržat počet mechanicky poranených stromov pod hranicou $10 \%$. Pomocou štatistického overenia sa zistilo, že poškodenie ostávajúceho porastu významne ovplyvňuje sila zásahu.

Harvester JD 1070 D pracujúci vo výchovných tažbách dosahoval pri priemernej objemnosti stromov $0,14 \mathrm{~m}^{3}$ a sklone svahu do $10 \%$ priemernú výkonnost̂ len 2,3 $\mathrm{m}^{3} \cdot \mathrm{h}^{-1}$. 
Zistilo sa, že správnou technologickou prípravou pracoviska a prispôsobením technických parametrov stroja parametrom spracovávaného porastu možno znížit náklady na výrobu $1 \mathrm{~m}^{3}$ na polovicu.

Klúčové slová: harvester, forwarder, výkonnost', spotreba PHM, poškodenie ostávajúceho porastu

\section{Introduction}

Harvester technologies bring on one side high performance and labour safety but on the other side their applying requires very precise preparation of technological process and workplaces as well as put high demands on qualification and psychic stability of their operators. Only meeting these requirements may guarantee effective use of these technologies and thus equalling the costs of $1 \mathrm{~m}^{3}$ of wood production comparable with traditional technologies for wood production or even lower. Based on the assessment of the knowledge from the use of harvester technologies in the years 2004-2007 we may state that it is necessary to take into consideration also risks arising during harvester technologies use. We deal with the issue of damage to remaining trees during tending treatments as well as with potential endangerment of wood-producing forest function and ecological function of forest soil by travel of heavy machines.

\section{Materials and methods}

\subsection{Material}

Experimental materials was collected at OZ Beňuš, Kriváň, Čierny Balog and ProPopulo Poprad Ltd. during harvester operation in tending felling and salvage felling. In case of OZ Beňuš we obtained data also from the operation of harvester in regeneration felling.

We measured operation of harvester and forwarder Valmet 911.1/6 + Valmet 840.1/8, JD 1070 D + JD $810 \mathrm{D}$ a JD $770 \mathrm{D}+\mathrm{JD} 810 \mathrm{D}$ in tending felling.

In case of harvester + forwarder Valmet 911.1/6 and Valmet 840.1/8 we measured intensity of mechanical damage to aboveground parts of trees in remaining stand at the age of 50 years. Effects of harvester technology were detected on plot 242B at OZ Beňuš and on plots 322, 326a, 327 and 329 at OZ Kriváň. Harvester and forwarder JD 1070 D + JD 810 D and harvester and forwarder JD 770 D + $810 \mathrm{D}$ were used in tending felling of coniferous stands at the age $35-40$ years at forest district Polianky (OZ Kriváñ) that were at the same time damaged by dispersed calamity. In both cases natural and production a condition were identical as well as stands were dense without any previous treatment with slope inclination from $10 \%$ to $20 \%$.

Work of harvester technologies during salvage felling was recorded at OZ Čierny Balog and ProPopulo Poprad Ltd. while at OZ Čierny Balog (forest district Krám) harvester and forwarder JD 1270 D + JD $1110 \mathrm{D}$ processed trees attacked by bark beetles in 80-year old spruce stand with admixture of beech, fir and maple. Harvester JD 1270 D produced 6, 4 or $2 \mathrm{~m} \operatorname{logs}$ that were collected and transported to the roadside landing by forwarder JD 1110 D. At ProPopulo Poprad Ltd. (stand 1016a) there was processed tree top calamity in spruce monoculture and harvester and forwarder JD $1270 \mathrm{D}+\mathrm{JD} 1110 \mathrm{D}$ were used. This technology was applied in 70-year old spruce stand on slope with inclination within 20\% and the proportion of broken trees was about $70 \%$.

Measurements of technological parameters of harvester JD $1270 \mathrm{D}$ were performed at OZ Beňuš, LS Beňuš. Harvester operated in regeneration felling of spruce stand whereas releasing felling in stripes with secured natural regeneration of spruce and artificial regeneration with beech and valuable broadleaves undergrowth was performed. Harvester JD 1270 D produced logs and forwarder JD 1110 D was skidding. 
Brief characteristic of natural-production conditions of respective workplaces is presented in table 1.

Table 1. Natural and production conditions

\begin{tabular}{|c|c|c|c|c|c|c|c|}
\hline $\begin{array}{c}\text { Harvester + } \\
\text { forwarder }\end{array}$ & Felling & 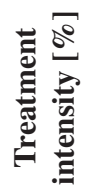 & Locality & $\begin{array}{l}\text { Work } \\
\text { shift } \\
\text { [Hour] }\end{array}$ & 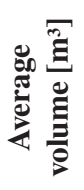 & $\begin{array}{c}\text { Slope } \\
{[\%]}\end{array}$ & 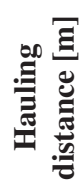 \\
\hline $\begin{array}{c}\text { Valmet } \\
911.1 / 6+840.1 / 8\end{array}$ & Tending to 50 years & 30 & $\begin{array}{l}\text { OZ Beňuš } \\
\text { OZ Kriváň }\end{array}$ & 24 & 0.22 & $20-30$ & 300 \\
\hline $\begin{array}{c}\text { JD } \\
1070 \mathrm{D}+810 \mathrm{D} \\
\end{array}$ & $\begin{array}{l}\text { Tending to } 50 \text { years } \\
\text { + Calamity }\end{array}$ & 40 & OZ Kriváň & 12 & 0.14 & Within 10 & 400 \\
\hline $\begin{array}{c}\text { JD } \\
770 \mathrm{D}+810 \mathrm{D}\end{array}$ & $\begin{array}{c}\text { Tending to } 50 \text { years } \\
+ \text { Calamity }\end{array}$ & 40 & OZ Kriváň & 12 & 0.19 & Within 10 & 450 \\
\hline $\begin{array}{c}J D \\
1270 \mathrm{D}+1110 \mathrm{D}\end{array}$ & $\begin{array}{c}\text { Bark beetles calami- } \\
\text { ty } 80 \text { years }\end{array}$ & 100 & $\begin{array}{l}\text { OZ Čierny } \\
\text { Balog }\end{array}$ & 12 & 1.31 & $10-20$ & 1100 \\
\hline $\begin{array}{c}\text { JD } \\
1270 \mathrm{D}+1110 \mathrm{D}\end{array}$ & $\begin{array}{l}\text { Tending to } 50 \text { years } \\
\text { - Tree top calamity }\end{array}$ & 54 & $\begin{array}{l}\text { ProPopulo } \\
\text { Poprad }\end{array}$ & 12 & 0.7 & Within 10 & 200 \\
\hline $\begin{array}{c}\text { JD } \\
1270 \mathrm{D}+1110 \mathrm{D}\end{array}$ & $\begin{array}{c}\text { Regeneration felling } \\
110 \text { years }\end{array}$ & 50 & OZ Beňuš & 10 & 1.03 & Within 10 & 240 \\
\hline
\end{tabular}

\subsection{Methods}

We aimed at measurements of parameters of harvester and forwarder operation in stand. We recorded necessary data as much as possible needed for the determination of machine performance, time demands of individual works and consumption of fuel in respective work conditions. Finding negative impacts of the technology on stand and soil was a part of the measurements. We detected damage on experimental plots that were established to copy the stand with required accuracy and reliability. We used German method of detecting damage to stand and soil modified at MZLU in Brno (Ulrich et al. 2002). Intensity of mechanical damage to aboveground parts of trees in remaining stand was detected in accordance with the methodology by Meng (1978) and classified according to Butora a Schwager (1989).

To find the performance of harvester (volume of timber processed for certain time unit) as well as for analysis of individual factors influencing the performance we carried out detailed time record of individual operations. Simultaneous measuring and recording individual operations of harvester is very demanding. Therefore we used output from computer on harvester performance (supplement 26 and 27) as a basis for the determination of number of trees, volume of timber and particularly for obtaining an overview of total structure and use of working time.

Time record is divided into respective parts of logging-transportation process as follows:

Travel - section of work operation starting with travel of machine after finishing tree assorting to the trees which the operators wants to process.

Stem grappling - section measured from the end of travel up to stem grapple by harvester head.

Delimbing, crosscutting - section is measured from the beginning of tree cutting followed by delimbing whereas time needed for cutting of logs and their sorting is being recorded until cutting of tops of trees. 
Felling waste piling - section measured from last log cutting until piling of top and branches.

Line clearing - measuring of section during which operator removes root balls or felling waste from the planned route of line.

Idle time - break for rest, check-up of workplace, checking of power saw chain, etc.

Stand - check-up of workplace, marking of treatment.

Repairs and maintenance - time needed for maintenance and repair of machine (chain exchange, service check-up and so on).

Transport - time needed for harvester transportation between respective workplaces.

Refuelling - time needed for refuelling.

Handling - total time for stems handling, logs and logging waste piling, line clearing.

During measurements we recorded basic data on forwarder operation needed for the calculation of its performance under given natural-production conditions. The structure of measurements was as follows:

- Travel to stand - distance (m), time consumption (min),

- Loading - distance ( $\mathrm{m})$, time consumption ( $\mathrm{min})$,

- Travel with load - distance (m), time consumption (min),

- Unloading - time consumption (min), number of cycles (n),

- Volume of timber $\left(\mathrm{m}^{3}\right)$,

- Idle time ( $\mathrm{min})$.

Measurement of fuel consumption was performed as follows.

As panel computer of machines used in harvester technologies registers also the volume of fuel in tank and this serves for evidencing fuel consumption in the accountancy records, it was not necessary to assemble in a fuel system of machines a special measuring instrument for fuel consumption. In the beginning of measurements machine was stopped near to the roadside landing on a plain place, motor was switched off and some time was left for fuel to stop fluctuate in the fuel tank. After 5 minutes proportion of tank filling was read from panel computer in \%. At the same time operation hours (mth) of machine were read as well from panel computer. They were recorded with accuracy $0.1 \mathrm{mth}$. Thus we obtained primary data necessary for further calculations.

When the measurements were ended the machine was parked at the same place as in the beginning and under the same conditions percentage of the tank filling by fuel and number of operation hours were read from panel computer.

Consumption of fuel for the observed time was detected from the difference in the percentage of tank filling by fuel in the beginning and at the end of measurements. Consumption in litres was detected from the calculated difference multiplied by volume of tank using the data contained in technical documentation of the machine. Worked operation hours were calculated as difference in the value in the beginning and end of measurements. Standardised consumption was calculated by dividing real consumption by the number of operation hours.

For processing measured data we used usual methods of mathematical statistics:

- At first check-up of extreme values was performed where Dixon's test was used that enables to exclude from the set of data illogically low and high values,

- Using software product Statistica we calculated necessary statistical characteristics of the sets of measured data - average, directive deviation, variation coefficient,

- We found and verified statistical dependencies between the sets of data by means of correlation and regression analysis of software product Excel. Statistical significance of regression relations was evaluated by comparing calculated correlation coefficients or correlation indexes (for non-linear relations) with the tables of their critical values. Statistical significance of regression coefficients was evaluated by using Student's t-test whereas zero hypothesis was that value of regression coefficient equals zero.

- Evaluation of statistical significance of differences between sets of values measured under various natural and production conditions was performed by the methods of dispersion analysis (variance analysis - ANOVA). 


\section{Results}

3.1. Damage to remaining stand

In case of harvester and forwarder Valmet 911.1/6 + Valmet 840.1/8 we aimed at measuring the intensity of mechanical damage to aboveground parts of trees in remaining stand at the age to 50 years at OZ Beňuš and OZ Kriváñ. We established 36 experimental plots in total in the stands 322, 242b 326a, 327 and 328a.

Relatively great variation range of characteristics as slope inclination $\mathrm{J}(\%)$, density of stand $\mathrm{H}\left(\mathrm{pcs} / \mathrm{ha}^{-1}\right)$ and treatment intensity $\mathrm{Z}$ (percent of the number of removed trees) were used for statistical verification of the significance of the effect of these characteristics (factors) on the intensity of trees wounds. Significant effect of original density of stand on the number of wounds (Fig. 1) was proved with help of regression analysis. The dependence has linear course whereas the number of damaged remaining trees grows with the density of stand. Correlation coefficient $r=0.745$ characterizes close dependencies. It indicates that regression dependence is statistically significant at the level of $5 \%$ significance $\left(r_{0.05}=0.669\right)$.

Another characteristic of stands being processed is distance of a tree from the line, which affects significantly the number of damaged trees in remaining stand. It is illustrated in figure 2 . As we can see in the figure 3 , the number of wounds is greatest in the distance within $1 \mathrm{~m}$ from the line (49.7\%), then number of damage drops up to the distance of about $5 \mathrm{~m}$, and then it starts to grow again.

Coefficient of relation determination is 0.787 what proves of close statistical dependence that explains the given relation in $78.7 \%$. The dependence of the number of trees wounds on their locations on the trees and distance from the skidding line for all stands is illustrated in the figure 3. Greater occurrence of wounds in concrete location is illustrated in bubble graph by greater diameter of the bubble. The number of wounded trees in the studied stands ranged from $6.6 \%$ to $10.8 \%$ (average $9.0 \%$ ). We must note that presented results were obtained during permanent operation of

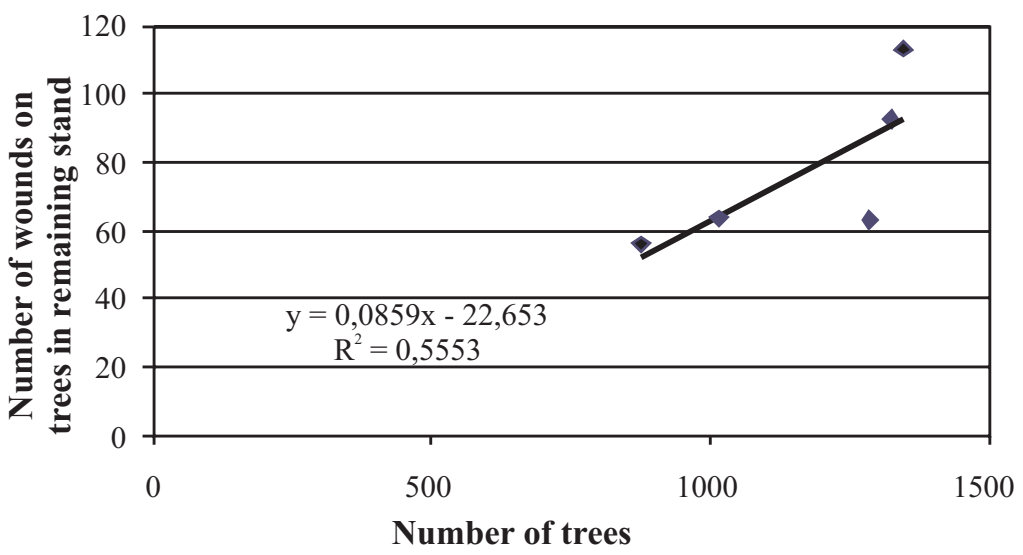

Fig. 1. Dependence of damaged trees on the density of stand. 


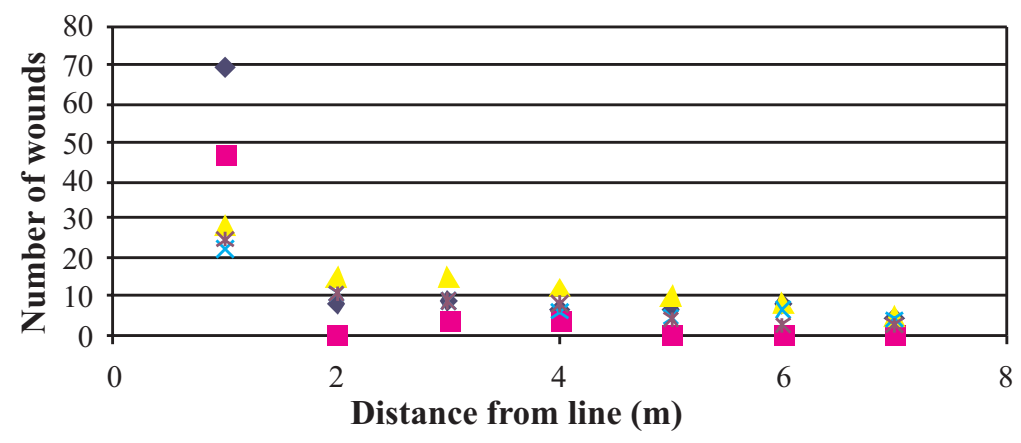

Porast $242 \mathrm{~b} \square$ Porast $322 \triangle$ Porast $327 \times$ Porast $326 \mathrm{a}$ X Porast $328 \mathrm{a}$

Fig. 2. Dependence of the number of damaged trees on their distance from the line.

Number of occurrence of wounds on trees

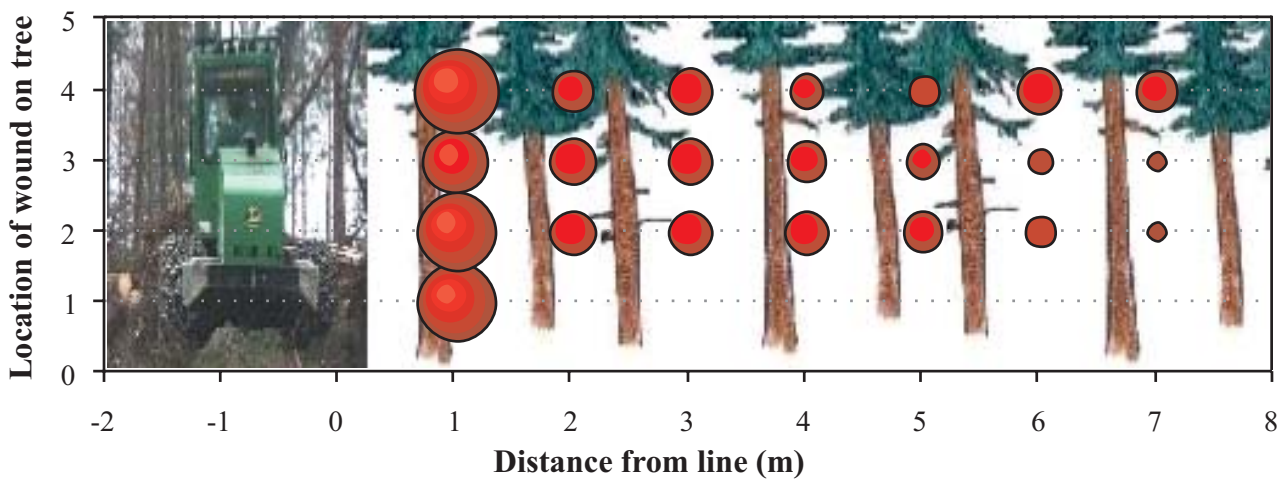

Fig. 3. Number of occurrence and location of wounds on trees.

Explanatory notes: Tree location - Classification of mechanical damage to tree according to the place of wound on tree BUTORA and SCHWAGER (1989)

machines (difference in the quality of work by day and by night was about $3 \%$ ).

Identical measurements were performed at OZ Kriváň during the operation of harvester and forwarder JD $1070 \mathrm{D}+810 \mathrm{D}$ a $770 \mathrm{D}+810 \mathrm{D}$. Intensity of damage to trees on individual plots ranged from 3\% to $15.5 \%$ (average $9 \%$ ). Almost $40 \%$ of all wounds were found in the distance smaller than $1 \mathrm{~m}$ from the line while almost $67 \%$ of them were at the height of more than $1 \mathrm{~m}$ from the ground (Fig. 4).

Greatest damage to remaining stand was recorded during the operation of harvester and forwarder JD $1270 \mathrm{D}+1110 \mathrm{D}$ processing tree top calamity in 70-year old spruce stand. Intensity of damage to trees remaining in the stand ranged from $11 \%$ to $25 \%$. 


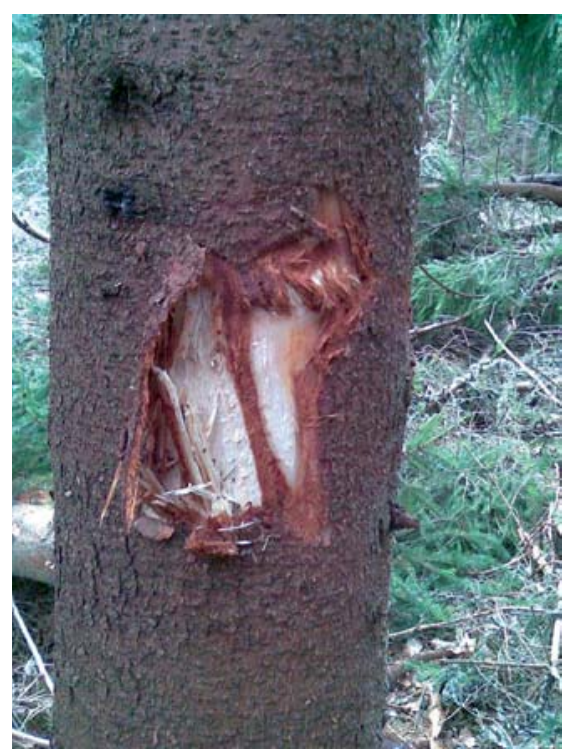

Fig. 4. Tree wound caused by harvester (Photo: Slamka, 2008)

Other measurements were performed at OZ Kriván̆ during the operation of harvester and forwarder JD 1070 D - 810 D + 770 D - 810 D. We established 24 control plots with aim to find out damage to remaining stand. Intensity of damage to trees on the plots ranged from $3 \%$ to $15.5 \%$ (average $9 \%$ ).

Almost $40 \%$ of wounds were found in the distance smaller than $1 \mathrm{~m}$ from the line and almost $67 \%$ of them were at the height more than $1 \mathrm{~m}$ from the ground (Fig. 4).

We found greatest damage to remaining stand during the operation of harvester and forwarder JD $1270 \mathrm{D}+1110 \mathrm{D}$ processing tree top calamity of 70-year old spruce stand when the intensity of damage to remaining trees ranged from $11 \%$ to $25 \%$.

Summary of measured results is given in table 2 .

Table 2. Results of measurements of damage to remaining stand using harvester technologies

\begin{tabular}{|c|c|c|c|c|}
\hline $\begin{array}{c}\text { Harvester }+ \\
\text { forwarder }\end{array}$ & Felling & $\begin{array}{c}\text { Treatment } \\
\text { intensity }\end{array}$ & Locality & $\begin{array}{c}\text { Average } \\
\text { damage }\end{array}$ \\
\hline $\begin{array}{c}\text { Valmet } \\
911.1 / 6+840.1 / 8\end{array}$ & Tending to 50 years & $20 \%-30 \%$ & $\begin{array}{c}\text { OZ Beňuš } \\
\text { OZ Kriván }\end{array}$ & $\begin{array}{c}6.6 \%-10.8 \% \\
\text { Average } 9 \%)\end{array}$ \\
\hline $\begin{array}{c}\text { JD } \\
1070 \mathrm{D}+810 \mathrm{D}\end{array}$ & $\begin{array}{c}\text { Tending to 50 years }+ \\
\text { Calamity }\end{array}$ & $40 \%$ & OZ Kriváň & $\begin{array}{c}3 \%-15.5 \% \\
\text { (Average } 9 \%)\end{array}$ \\
\hline $\begin{array}{c}\text { JD } \\
1270 \mathrm{D}+1110 \mathrm{D}\end{array}$ & $\begin{array}{c}\text { Tending above } 50 \text { years } \\
\text { - Tree top calamity }\end{array}$ & $54 \%$ & $\begin{array}{c}\text { ProPopulo } \\
\text { Poprad }\end{array}$ & $\begin{array}{c}11 \%-25 \% \\
\text { (Average } 17 \%)\end{array}$ \\
\hline
\end{tabular}




\subsection{Measurement of performance and consumption of fuel}

Performance of harvester and forwarder JD 1070 D + JD 810 D was observed in tending felling in forests managed by OZ Kriváň. Harvester reached in one-shift operation (12 hours) average performance $2.3 \mathrm{~m}^{3} \cdot \mathrm{h}^{-1}$ with average volume of tree $0.14 \mathrm{~m}^{3}$ and slope inclination within $10 \%$. It is only $40 \%$ in comparison with the performance $5.7 \mathrm{~m}^{3} \cdot \mathrm{h}^{-1}$ reached during 8.5 -month operation. Average daily performance was $15.90 \mathrm{~m}^{3}$ of produced assortments whereas harvester of this kind can reach daily performance about $100 \mathrm{~m}^{3}$ per day under optimal conditions.

Mainly following factors caused low performance of harvester:

- Density of processed stand, dense undergrowth formed of thin and in many cases almost dried spruce trees that hinder head entering the stand and therefore it must be disassembled. Then produced assortments are piled together with felling waste (tops and branches) whereas this material forms almost $40 \%$ of total processed wood,

- Invisible marking of trees, invisible colour used for making, marking of trees was done only on one side of tree,

- Reach of hydraulic boom is not used in its full range due to high density of stand,

- Parameters of used machine were not adjusted to the parameters of processed stand.

Performance of forwarder was $10.8 \mathrm{~m}^{3}$ of large timber per hour with skidding distance $400 \mathrm{~m}$, what means time consumption $0.093 \mathrm{~h} . \mathrm{m}^{-3}$. Harvester and forwarder JD $1070 \mathrm{D}+\mathrm{JD} 810 \mathrm{D}$ produced and skidded under given natural-production conditions $1 \mathrm{~m}^{3}$ of large timber per 0.768 hour. With regard to low performance production costs of $1 \mathrm{~m}^{3}$ of wood were calculated to 2,173 SKK.

More favourable results were obtained for harvester and forwarder JD $770 \mathrm{D}+$ JD 810 DV under comparable conditions. Calculated costs of the production of $1 \mathrm{~m}^{3}$ of wood were "only" 1,094 SKK. In this case there was used in the stand a machine with corresponding parameters and lower fuel consumption, and trees designated for felling were marked better. Resultant costs are influenced considerably also by purchase price of a new machine.

Other measurements were performed in stand damaged by bark beetle calamity at OZ Čierny Balog where harvester and forwarder JD 1270 D + JD 1110 D was operating in 80-year old spruce stand with admixture of beech, fir and maple. Harvester JD $1270 \mathrm{D}$ produced 6, 4 or 2-m long logs and forwarder JD $1110 \mathrm{D}$ was collecting and skidding timber to roadside landing. Skidding distance was 1,000 up to $1,200 \mathrm{~m}$, slope inclination on the skidding line $17 \%$ in the $400 \mathrm{~m}$ part and within $10 \%$ in remaining part. Detailed time record was made to find out the performance.

The forwarder transported 9 loads of logs; of them 5 loads were 6-m long logs and 4 loads were 4-m long logs during work shift. Average volume of timber in one load was $13.26 \mathrm{~m}^{3}$ for $6-\mathrm{m}$ long logs and $11.96 \mathrm{~m}^{3}$ for 4-m long logs. Total volume of skidded wood was about $114 \mathrm{~m}^{3}$. Average net time per one working cycle was 70 minutes. Measured data are given in table 3. Consumption of fuel per one working cycle was evaluated on the basis of data from forwarder computer (percentage of fuel 
Table 3. Measured data necessary for the calculation of forwarder JD $1110 \mathrm{D}$ performance

\begin{tabular}{|c|c|c|c|c|c|c|c|c|c|c|}
\hline \multirow{3}{*}{ 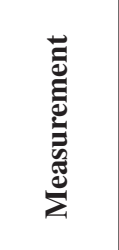 } & \multirow{2}{*}{\multicolumn{2}{|c|}{$\begin{array}{c}\text { Travel to } \\
\text { stand }\end{array}$}} & \multirow{2}{*}{\multicolumn{2}{|c|}{$\begin{array}{c}\text { Load } \\
\text { assembly }\end{array}$}} & \multirow{2}{*}{\multicolumn{2}{|c|}{$\begin{array}{c}\text { Travel } \\
\text { with load }\end{array}$}} & \multicolumn{2}{|c|}{ Piling at the roadside } & \multirow{3}{*}{ 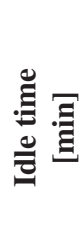 } & \multirow{3}{*}{$\begin{array}{c}\begin{array}{c}\text { Total time } \\
\text { consumption }\end{array} \\
\text { Min }\end{array}$} \\
\hline & & & & & & & \multirow{2}{*}{$\begin{array}{c}\begin{array}{c}\text { Time } \\
\text { consumption }\end{array} \\
\text { Min }\end{array}$} & \multirow{2}{*}{$\begin{array}{c}\text { Number } \\
\text { of piling } \\
\text { cycles }\end{array}$} & & \\
\hline & $\mathbf{m}$ & Min & $\mathbf{m}$ & Min & $\mathbf{m}$ & Min & & & & \\
\hline 1 & 1000 & 16.2 & 56 & 17.8 & 1000 & 26.3 & 5.3 & 13 & 5.0 & 70.6 \\
\hline 2 & 1000 & 17.0 & 62 & 19.1 & 1000 & 28.0 & 4.7 & 11 & & 68.8 \\
\hline 3 & 1000 & 15.3 & 55 & 16.5 & 1000 & 23.6 & 5.6 & 12 & 30.0 & 91.0 \\
\hline 4 & 1200 & 15.8 & 40 & 16.0 & 1200 & 27.0 & 5.0 & 11 & & 63.8 \\
\hline 5 & 1200 & 16.1 & 72 & 17.3 & 1200 & 24.2 & 6.1 & 17 & & 63.7 \\
\hline 6 & 1200 & 16.6 & 44 & 16.7 & 1200 & 24.7 & 4.8 & 12 & 15.0 & 77.8 \\
\hline 7 & 1200 & 15.6 & 54 & 18.3 & 1200 & 23.7 & 5.2 & 13 & 9.0 & 71.8 \\
\hline 8 & 900 & 14.9 & 47 & 15.0 & 900 & 22.3 & 6.3 & 14 & & 58.5 \\
\hline 9 & 900 & 14.6 & 56 & 14.8 & 900 & 27.0 & 5.1 & 11 & & 61.5 \\
\hline Total & 9600 & 142.1 & 486 & 151.5 & 9600 & 226.8 & 48.1 & 114 & 59.0 & 627.5 \\
\hline Average & 1067 & 15.8 & 54 & 16.8 & 1067 & 25.2 & 5.3 & 12.7 & 6.5 & 69.7 \\
\hline
\end{tabular}

in the tank) and it ranged from 10.2 up to 12.6 litres. Average calculated consumption of fuel per one working cycle was 12.11 what was under given conditions $12.11 . \mathrm{mth}^{-1}$. Based on these data calculated consumption of fuel per one cubic meter of skidded timber was 1.05 l. Time demands of individual operations are evaluated in figure 5.

\section{LS Krám}

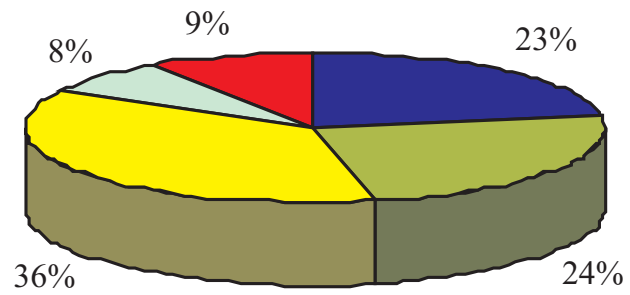

Travel to stand $\square$ Loading $\quad \square$ Travel with load

Unloading $\square$ Idle time

Fig. 5. Time demand of forwarder $1110 \mathrm{D}$ for skidding to the distance $1,000 \mathrm{~m}$. 
Work of harvester $1270 \mathrm{D}$ was evaluated only on the basis of working day record. Harvester was processing wood in stand 335 that was affected by bark beetle calamity. Average volume of stem was $1.31 \mathrm{~m}^{3}$. Harvester processed $108.55 \mathrm{~m}^{3}$ of wood per one shift (12 hours) and average performance reached $13.53 \mathrm{~m}^{3} \cdot \mathrm{h}^{-1}$ of work. Trees that harvester could not process due to their big dimensions were processed by power saws (motomanual technology). Performance per one shift was influenced by service check-up that lasted for 140 minutes.

Measurements of technological parameters of harvester and forwarder JD 1270 D + JD $1110 \mathrm{D}$ were performed at OZ Beňuš. Harvester and forwarder worked in regeneration felling of spruce stand whereas liberation felling in strips was performed in secured natural regeneration of spruce and artificial regeneration with underplanting of beech and valuable broadleaved species. There were produced assortments as saw logs long $4 \mathrm{~m}$ and pulpwood long $2.5 \mathrm{~m}$. Forwarder JD $1110 \mathrm{D}$ was skidding the logs. Measurements were carried out during 8 working cycles while average distance of travel with load was $242 \mathrm{~m}$ and average distance of travel, when forwarder was gathering wood from piles, was $94 \mathrm{~m}$.

During the measurements 110 trees were processed with total volume $113.44 \mathrm{~m}^{3}$ and $787 \operatorname{logs}$ were produced. Performance per one hour of work was $23.46 \mathrm{~m}^{3}$.

Consumption of fuel was calculated from the values of fuel percentage in the tank and operation hours that were recorded in the beginning and at the end of measurements. Fuel consumption was $13.21 . \mathrm{mth}^{-1}$.

Table 4. Performance and consumption of fuel in harvesters

\begin{tabular}{|c|c|c|c|c|c|c|c|c|}
\hline \multirow{2}{*}{ Harvester } & \multirow{2}{*}{$\begin{array}{c}\text { Locality } \\
\text { OZ }\end{array}$} & \multicolumn{2}{|c|}{ Performance } & \multirow{2}{*}{$\begin{array}{c}\text { Treatment } \\
\text { intensity } \\
{[\%]}\end{array}$} & \multirow{2}{*}{$\begin{array}{c}\text { Fuel con- } \\
\text { sumption } \\
{\left[\text { l.mth }^{-1}\right]}\end{array}$} & \multirow{2}{*}{$\begin{array}{c}\text { Stem } \\
\text { volume } \\
{\left[\mathrm{m}^{3}\right]}\end{array}$} & \multirow{2}{*}{ Kind of felling } & \multirow{2}{*}{$\begin{array}{c}\text { Slope } \\
{[\%]}\end{array}$} \\
\hline & & $\mathbf{m}^{3} \cdot \mathbf{m t h}^{-1}$ & $\mathbf{m}^{3} \cdot \mathbf{h}^{-1}$ & & & & & \\
\hline Valmet 911.1 & Beňuš & 8.28 & - & 22 & - & 0.2 & Tending $50 \mathrm{y}$. & 35 \\
\hline Valmet 911.1 & Kriváň & 5.30 & - & 34 & - & 0.12 & Tending $50 \mathrm{y}$. & 40 \\
\hline JD $1070 \mathrm{D}$ & Kriváň & - & 2.3 & 40 & 13.7 & 0.14 & Tending $35 \mathrm{y}$. & 10 \\
\hline JD 770 D & Kriváň & 2.3 & - & 40 & 8.7 & 0.19 & Tending $35 \mathrm{y}$. & 10 \\
\hline JD $1270 \mathrm{D}$ & Beňuš & - & 23.5 & 40 & 13.2 & 1.03 & Regeneration $110 \mathrm{y}$. & 10 \\
\hline JD $1270 \mathrm{D}$ & Č. Balog & - & 13.5 & 100 & 13.2 & 1.31 & Salvage $80 \mathrm{y}$ & 17 \\
\hline
\end{tabular}

Table 5. Performance and fuel consumption of forwarders

\begin{tabular}{|c|c|c|c|c|c|c|}
\hline Forwarder & $\begin{array}{l}\text { Locality } \\
\text { OZ }\end{array}$ & $\begin{array}{c}\text { Performance } \\
{\left[\mathbf{m}^{3} \cdot \mathbf{h}^{-1}\right]}\end{array}$ & $\begin{array}{l}\text { Stem volume } \\
\text { in }\left[\mathrm{m}^{3}\right]\end{array}$ & $\begin{array}{c}\text { Skidding } \\
\text { distance }[\mathrm{m}]\end{array}$ & $\begin{array}{c}\text { Fuel consumption } \\
{[\text { [.mth-1] }}\end{array}$ & $\begin{array}{c}\text { Time of } \\
\text { loading [\%] }\end{array}$ \\
\hline JD $810 \mathrm{D}$ & Kriváň & 1.9 & Felling waste & $30-90$ & 7.4 & 57 \\
\hline JD $1110 \mathrm{D}$ & Č. Balog & 10.8 & 1.31 & $1,000-1,200$ & 12.1 & 24 \\
\hline JD $1110 \mathrm{D}$ & Beňuš & 14.7 & 1.03 & 420 & 11.8 & 55 \\
\hline
\end{tabular}


Table 6. Time consumption and costs of harvester and forwarder

\begin{tabular}{|c|c|c|c|c|c|}
\hline \multicolumn{2}{|c|}{ Harvester + forwarder } & \multirow{2}{*}{$\begin{array}{c}\text { Stem } \\
\text { volume } \\
{\left[\mathrm{m}^{3}\right]}\end{array}$} & \multirow{2}{*}{$\begin{array}{c}\text { Skidding } \\
\text { distance } \\
{[\mathrm{m}]}\end{array}$} & \multirow{2}{*}{$\begin{array}{c}\text { Time } \\
\text { consumption } \\
{\left[{\left.\mathrm{h} . \mathrm{m}^{-3}\right]}^{-3}\right.}\end{array}$} & \multirow{2}{*}{$\begin{array}{c}\text { Costs } \\
{\left[\mathrm{SKK}^{-3} \mathbf{m}^{-3}\right]}\end{array}$} \\
\hline Harvester & Forwarder & & & & \\
\hline JD $1070 \mathrm{D}$ & JD $810 \mathrm{D}$ & 0.14 & 400 & 0.768 & 2173 \\
\hline JD $770 \mathrm{D}$ & JD $810 \mathrm{D}$ & 0.19 & 450 & 0.609 & 1094 \\
\hline JD $1270 \mathrm{D}$ & JD $1110 \mathrm{D}$ & 1.31 & $1,000-1,200$ & 0.152 & 420 \\
\hline JD $1270 \mathrm{D}$ & JD $1110 \mathrm{D}$ & 1.03 & 242 & 0.123 & 340 \\
\hline
\end{tabular}

Performance of forwarder JD $1110 \mathrm{D}$ under given natural-production conditions was calculated to be $14.70 \mathrm{~m}^{3}$ per one hour of work, consumption of fuel $11.81 . \mathrm{mth}^{-1}$.

Summary of the data measured at respective workplaces is presented in tables 4 , 5 and 6.

\section{Discussion and conclusions}

Reaching high performance with simultaneous reduction or elimination of mechanical damage to remaining trees is one of principal problems in applying multi-operational machines in timber felling and processing. Hydromanipulator of harvester and of forwarder, harvester head with careless travel of machine cause mechanical injuries of trees most frequently. Another reason of damage may be also small experience of operators or low quality of technological preparation of a workplace (LUKÁČ 2005). DvořÁK (2008) notes that mostly (88.5\%) moving by tree caused damage to remaining stand and it may be influenced also by tree length. Machine causes only $11.1 \%$ of injuries. Dvoř́x also notes that in tree-length logging and full-tree logging technology applied in tending felling there are damaged $22 \%-25 \%$ of trees remaining in stand, and in assortment technology $5 \%$ of remaining trees are damaged. Harvester technologies cause damage from $1.2 \%$ to $5.9 \%$, while in manual skidding there are damaged $3.4 \%-5.6 \%$ of trees, in skidding by horses $1.9 \%-17.7 \%$ of trees, skidding by universal wheeled tractor UKT it is $5.7 \%-25 \%$, for combination horse + UKT $6.6 \%-34 \%$ and cable system $34 \%$.

Results of SimANOv (1998) are similar when he notes the damage on average only $2.1 \%$ of trees remaining in stand for the use of mechanized assortment method (harvester and forwarder), $3.7 \%$ for tree-length logging and timber skidding by horses, $6.9 \%$ for combined skidding by horses + UKT and $10.4 \%$ for using the combination horses + SLKT (special forestry wheeled tractor). SimANOv considers these results, which are favourable for harvester technologies, logical and he justifies them by permanent check-up and perfect directional cutting that minimises damage to stand. SIRÉN (2000) was studying damage to trees during felling by harvester in low thinning in 15 stands on the area of 14.7 hectares with 9 experimental plots each of them with $30 \mathrm{~m}^{2}$. Damage to trees ranged from $1.1 \%$ to $9.1 \%$ (average $4.6 \%$ ) what SIRÉN (2000) considers still acceptable. Greater damage was recorded in summer felling (force needed to disturb 
the bark is $40 \mathrm{~N} . \mathrm{cm}^{-2}$ in time of intensive sap flow and $60-80 \mathrm{~N} . \mathrm{cm}^{-2}$ except for the mentioned period). SIRÉN recommends performing felling in non-vegetation period. Svadicani (2003) notes for selective thinning by harvester Silvatec 656TH (reach of boom $7 \mathrm{~m}$ ) productivity $13.5 \mathrm{~m}^{3} \cdot \mathrm{h}^{-1}$. Forwarder Valmet reached $10.8 \mathrm{~m}^{3} \cdot \mathrm{h}^{-1}$. Damage to stands was within $5 \%$.

We verified impacts of harvester technology on remaining stand in tending felling under the conditions of Central Slovakia at forest enterprises OZ Beňuš, OZ Kriván̆ and Pro Populo-Poprad Ltd. The obtained results show that with using machines on wheeled chassis on the slope with inclination $40 \%$ it is possible to keep the number of mechanically damaged trees below $10 \%$. It was found by means of statistical verification that damage to remaining stand is influenced significantly by the treatment intensity. Results reached at ProPopulo Poprad Ltd. prove of that when in processing heavy top tree calamity (average intensity of treatment was 54\%) average damage to remaining trees was $17 \%$.

Locations of trees injuries (location of wound on tree and distance of tree from the line) was evaluated on experimental plots at OZ Beňuš and ProPopulo Poprad Ltd. Taking into account the results it is obvious and logical as well that the greatest number of wounds are in places where was the highest frequency of machines movement, particularly in the distance within $1 \mathrm{~m}$ from working line.

SLUGEŇ (2007) and FERENČík (2009) also deal with the evaluation of negative effects of harvester technologies in the conditions of Slovakia. Ferenčík studied impacts of harvester technology in processing wood from calamity in the stands at the age to 50 years in upper Orava region. He states that average damage of $25 \%$ was caused by the kind of felling (processing of tree top calamity), that felling was performed in time of sap flow when spruce trees are extremely sensitive to bark injury as well as due to lack of experience of operators with this kind of felling. SLUGEŇ (2007) gives the average value of damage $17 \%$ in the conditions of Slovakia.

From economic viewpoint technology performance in felling is the most interesting factor. For harvester technologies it is the factor that influenced the most applying these technologies not only in processing extensive wind calamities but also in the forest management of Slovakia as a whole.

Our measurements were aimed at finding the performance of harvester and forwarder operating in tending felling at OZ Kriván. We found by comparing the work of harvesters with various technical parameters operating in comparable conditions that it is possible to reduce production costs of $1 \mathrm{~m}^{3}$ of wood to one half by proper technological preparation of the workplace and adjusting technical parameters of machine to the parameters of processed stand. Costs presented in table 6 could be reduced by financial realization of felling waste that in both cases represented almost $40 \%$ of total processed wood.

We found when studying performance and costs of $1 \mathrm{~m}^{3}$ of wood applying harvester and forwarder $1270 \mathrm{D}+1110 \mathrm{D}$ that performance is dependent considerably on skidding distance. In figure 5 it is obvious that with skidding distance $1,000-1,2000 \mathrm{~m}$ the time needed for travel to stand and travel with load accounts for almost $60 \%$ of 
total working cycle. We present figure 6 for comparison as it illustrates the structure of working cycle of forwarder with skidding distance $250 \mathrm{~m}$.

Despite high costs of the production of $1 \mathrm{~m}^{3}$ of wood we recommend applying harvester technology in tending felling. ILAVSKÝ, RADOCHA and KoCIANOvá (1992) consider humanization of work a major favourable impact of mechanization use in tending felling. It is particularly elimination of work with power saw in delimbing of thin trees and in timber handling what reflects favourable also in reduction of the amount of exhalation from engines and oils. Also SLUGEŇ (2007) recommends applying preferentially harvester technology for tending in younger stands (to the age of 50 years), where higher performance can be reached in comparison with applying traditional combined (mechanised + manual) technology as well as lower production costs of $1 \mathrm{~m}^{3}$ of wood.

We must not forget about the factor of wood cleanness, as during harvest wood is not in contact with soil at all.

Utilization of harvester technologies in spruce stands is highly effective also in salvage felling (calamities caused by wind or bark beetles) when due to high performance of these machines it is possible to process wood immediately and to deliver produced logs as fresh round wood what has direct effect on its realization price in comparison with round wood produced from snags and pulpwood.

Based on the obtained knowledge we propose following measures to improve applying harvester technologies in the forestry of Slovakia:

- With regard to high level of forestry education in Slovakia it is necessary to consider an idea of establishing a training centre that would provide training and courses for new operators and training for forest workers working with felling technology, as failure of human factor on management level is usually the most frequent reason of unsuccessful utilization of these technologies.

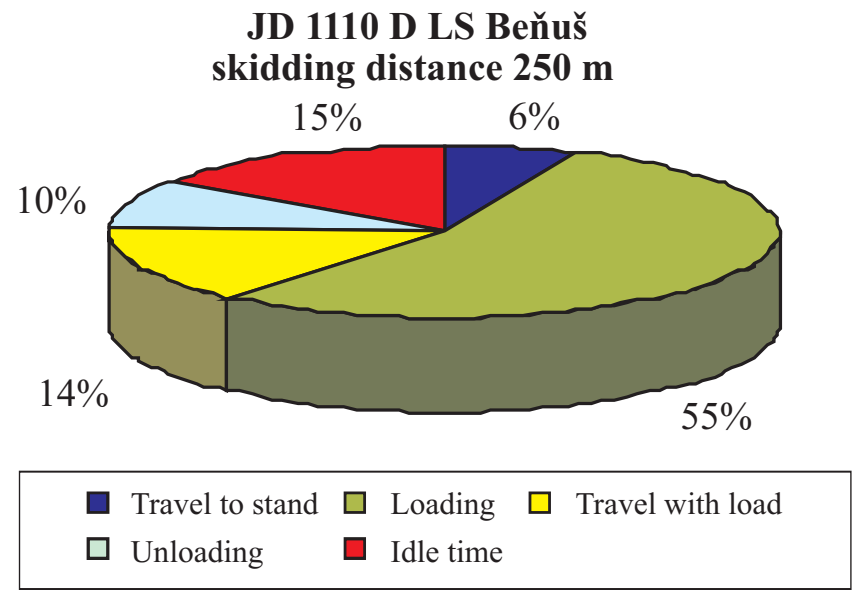

Fig. 6. Structure of work time of JD $1110 \mathrm{D}$ forwarder. 
- It is necessary to ensure proper marking of skidding lines and trees designated for felling with the presence of harvester operator to increase the effectiveness of harvester technology utilization in tending felling. Trees should be marked in a way to be visible well from the cabin of operator (using reflexive colour, colour strip being visible from all sides).

- In reviewing the effectiveness of harvester technology utilization in tending felling it is necessary to pay attention also to the purpose of utilization - what is providing insurance of good work organization performance of tending treatment in relatively short time to minimise damage to remaining stand (environmentally friendly tending treatment) with simultaneous maximal production of timber assortments and biomass.

- Shortcoming in collecting biomass produced during stand processing by harvester and forwarder is that fact in economic assessment of this technology the value of produced biomass is not considered due to time shift of its processing. Piles of collected biomass (small timber and felling waste) are frequently left at roadside landing also for several months unprocessed or unprotected against insects what creates preconditions for eventual reproduction of bark beetles.

- With regard to lowering negative impacts on remaining stand and soil it is necessary prior to tending treatment to determine on the basis of natural-production conditions the highest permitted limits of damage. It was found that the intensity of damage to remaining stand is proportional directly to the density of processed stand and trees located within $1 \mathrm{~m}$ distance from the line are damaged most frequently whereas damage caused by harvester prevail. Narrow working line is a significant factor conditioning damage to stand.

- If possible we recommend adjusting technical parameters of used machine to the parameters of stand. If it is not observed consequences may arise as not proportional increase of production costs, increased breakdown rate of machine and increased damage to remaining stand.

- Applying harvester technologies requires faultless functioning of logistic chain, mainly in salvage felling, as there is a risk of filling the area of the roadside landing resulting in undesirable idle time.

- It is necessary to incorporate to forest management plans also tending treatments in adjacent or continuous stands (according to forest roads), which are suitable for applying harvester technology, in a way the technology is used in the shortest possible time. In that way presuppositions for effective performance of works will be created (minimising financial costs and time losses needed for movement of machines to other place).

\section{References}

1. Butora A.; Schwager G., 1989: Holzernteschäden in Durchforstungsbeständen. Edigenössiche Anstalt für das Forstliche Versuchswesen, Birmensdorf, Berichte, č. 228, 51 s. - 2. DvoŘÁK J., 2008: Mechanické poškození a zhutnení půdy při nasazení harvesterových technologií na kalamitních plochách. In Integrované tažbovo-dopravné technológie. Zborník pôvodných vedeckých prác. Zvolen, TU Zvolen, s. 25 - 32. - 3. Ferenčík M., Messingerová V., Stanovský M., 2008: Analýza dopadu harvesterovej tech- 
nológie na lesné porasty vo flyšovom pásme Hornej Oravy. In Integrované łažbovo-dopravné technológie. Zborník pôvodných vedeckých prác. Zvolen, TU Zvolen, s. 33 - 42. - 4. KoreŇ J., SlugeŇ J., Slamka M., 2004: Mechanické poranenie stromov a zhutnenie pôdy pri plne mechanizovaných prebierkach $\mathrm{v}$ ihličnatých porastoch do 50 rokov. Acta facultatis forestalis, XLVI. Zvolen, TU Zvolen, s. 247 - 259. - 5. LuKáČ T., 2005: Viacoperačné stroje v lesnom hospodárstve. TU Zvolen, 2005, 137 s. - 6. Meng W., 1978: Baumverletzungen durch Transportvorgänge bei der Holzernte. Schriftenreihe der Landesforstverwaltung Baden-Württemberg Band 53, 159 s. - 7. Radocha M., Slamka M., 2008: Poznatky z využívania vyvážacích traktorov v lesoch SR. In Integrované tažbovo-dopravné technológie. Zborník pôvodných vedeckých prác. Zvolen, TU Zvolen, s. 139 - 142. - 8. SimAnov V., 1998: Harvestery ano - či ne?, Terra 5, 6/98, s. 8. - 9. SIRÉN M., 2000: Silvicultural results of one- grip harvester operation. Innternational Journal of forest engineering, č. 2, s. 7 - 14. - 10. Svadicani K., Nordfiell T., 2003: Operatinal aspects of eow and selective thinning in establishing of a shelterwood in 50-years old Norway spruce stand. International Journal of Forest Engineering, no. 1, p. 25 - 37. - 11. SLAMKA M., 2006: Lesnícka technika a spracúvanie veternej kalamity v lesoch vo Vysokých Tatrách. Lesnícky časopis - Forestry Journal, 52(3): 249 - 263. - 12. SlaMKA M., RADOCHA M., 2008: Poznatky z využívania harvesterových technológií $\mathrm{v}$ lesoch SR. In Integrované tažbovo-dopravné technológie. Zborník pôvodných vedeckých prác. Zvolen, TU Zvolen, s. 167 - 173. - 13. Tice B., 2003: A howling succes, Canadian Forest industries, s. 26-28. - 14. Ulrich R., SchlaghamerskÝ A., Štorek V., 2002: Použití harvesterové technológie v probírkách, Mendelova zemnědělská a lesnická univerzita v Brně, 98 s. + CD.

\section{Resumé}

V rámci OZ Beňuš, Kriváň, Čierny Balog a ProPopulo Poprad, s. r. o., sa vykonali merania výkonnosti, spotreby PHM a negatívnych dopadov pri práci harvesterových uzlov Valmet 911.1/6 + Valmet 840.1/8, JD 1070 D + JD 810 D, JD 770 D + JD 810 D a JD 1270 D + 1110 D. Pri použití strojov na kolesových podvozkoch na svahoch do sklonu $40 \%$ sa zistilo, že možno udržat počet mechanicky poranených stromov v priemere pod hranicou $10 \%$, pričom sa štatisticky overilo, že poškodenie ostávajúceho porastu významne ovplyvňuje sila zásahu.

Na základe zistenej výkonnosti strojov, nameranej spotreby PHM a d’alších dostupných údajov sa vypočítali náklady na výrobu $1 \mathrm{~m}^{3}$ dreva harvesterovým uzlom. Zistilo sa, že správnou technologickou prípravou pracoviska a prispôsobením technických parametrov stroja parametrom spracovávaného porastu možno znížit náklady na výrobu $1 \mathrm{~m}^{3}$ dreva o viac ako polovicu. V závere sa na základe získaných poznatkov navrhujú opatrenia na skvalitnenie použitia HT v rámci lesného hospodárstva SR. 